\title{
Viability of bacteria from different aquatic habitats. II. Cellular fluorescent markers for membrane integrity and metabolic activity
}

\author{
Rhena Schumann*, Ulrich Schiewer, Ulf Karsten, Thorsten Rieling
}

University of Rostock, Department of Life Sciences, Institute of Aquatic Ecology, A. Einstein Str. 3, 18059 Rostock, Germany

\begin{abstract}
We applied different types of fluorescent markers to natural bacterioplankton from different aquatic systems to investigate microscopically the percentage of viable bacteria. To characterise viable bacteria, cell-specific respiration was measured by cyanoditolyltetrazolium chloride (CTC) reduction. Membrane integrity was investigated with 3 'dead cell' stains (SYTOX ${ }^{\circledR}$ Green, propidium iodide and ethidium homodimer-2). Cellular enzyme activity was detected by artificial substrate analogs with a high cell retention (CellTracker ${ }^{\mathrm{TM}}$ Green CMFDA for cellular esterase and 7-amino-4-chloromethylcoumarin L-leucine amide, hydrochloride [CMAC-Leu] for cellular peptidase). The percentage of impermeable, i.e. morphologically intact, cells accounted for 22 to $81 \%$ of the total cell number at all locations. Although up to $48 \%$ of all bacteria were respiring, they averaged between 10 and $14 \%$ in freshwater, estuarine waters and in the Baltic Sea. The portion of esterase-positive cells correlated significantly with the concentrations of dissolved (DOC) and particulate organic carbon (POC) as well as with chlorophyll a (chl a) content. Cellular esterase was shown by this labelling technique in only $9 \%$ of freshwater, $12 \%$ of estuarine and $5 \%$ of Baltic Sea bacteria, . The percentages of bacteria with cellular peptidase were even lower with 6,5 and $3 \%$, respectively. The different amounts of intact and respiring bacteria as well as those with cellular hydrolytic enzyme activities require not only correct operational definitions of active and viable bacteria, but also the appropriate choice of fluorescent markers regarding the goals of investigation. Fluorescent labels for cellular hydrolytic enzymes will also provide a new tool to localise active cells in aggregates or on sediment particles, where, besides the respiration of organic carbon, hydrolysis of organic substances is an important conversion process.
\end{abstract}

KEY WORDS: Viability · Fluorescent stains $\cdot$ LIVE/DEAD kit · CMFDA $\cdot$ Cellular esterase $\cdot$ CMAC-Leu • Cellular peptidase $\cdot \mathrm{CTC} \cdot \mathrm{SYTOX} \cdot$ Propidium iodide $\cdot$ Membrane permeability $\cdot$ Pelagic bacteria $\cdot$ Respiring bacteria

Resale or republication not permitted without written consent of the publisher

\section{INTRODUCTION}

The quantification of metabolically active bacteria is important in studies of microbial production and growth rates, organic matter decomposition and for assigning microbial activities to individual organisms (e.g. Kogure et al. 1979, Rodriguez et al. 1992). There is a great variety of physiological reactions and states of bacteria which can be used to distinguish between inactive and active or permeabilised and intact cells.

The widely used test of the bacteria's ability to form colonies on agar plates is most certainly one of the securest signs of viability (Barcina et al. 1989, Bunthof et al. 1999). On the other hand, it is well known that only a very small percentage of aquatic bacteria grow on agar plates (e.g. Ferguson et al. 1984, Gocke \& Rheinheimer 1991). The same dividing ability is tested in the direct viable count method without the use of growth media by enumerating elongated cells after treatment with nalidixic acid (Kogure et al. 1979, Fiksdal \& Tryland 1999). The frequency of dividing cells is also used as a measure for viability (Hagström et al. 1979).

Another characteristic of intact and potentially viable cells is the integrity of the cell membrane and the trans-membrane potential. There are numerous nucleic acid-specific fluorescent markers that do not 
penetrate intact membranes: the so-called 'dead cell stains'. The most common is propidium iodide, which is also the dead cell counter-stain in the LIVE/DEAD ${ }^{\circledR}$ BacLight ${ }^{\mathrm{TM}}$ bacterial viability kit (Haugland 2001) and in the vital stain and probe technique (Williams et al. 1998). Propidium iodide has already been applied to natural bacterial assemblages (Yamaguchi \& Nasu 1997, Boulos et al. 1999). Other impermeant nucleic acid stains, such as TO-PRO (Novo et al. 2000) or SYTOX (Roth et al. 1997, Lebaron et al. 1998a), were also applied to bacterial isolates, especially to test antibiotics susceptibility or other stress factors. Markers sensitive for the electrochemical trans-membrane potential are of the oxonol-group, which are enriched in dead cells, and also rhodamine 123, which is accumulated in viable cells (Veal et al. 2000).

Respiratory activity of individual bacteria has also been used extensively to detect viable cells in aquatic samples. There are several tetrazolium salts that are reduced in respiring cells to dark coloured crystals (King \& Parker 1988, Posch et al. 1997) and cyanoditolyltetrazolium chloride (CTC) is reduced to red fluorescing formazan crystals (e.g. Rodriguez et al. 1992, Sherr et al. 1999a).

The activity of cellular hydrolytic enzymes, especially esterases, has been used for bacterial strains to investigate stress susceptibility (Diaper et al. 1992, Bunthof et al. 1999) and to show intracellular activity in phytoplankton (Dorsey et al. 1989, Murphy \& Cowles 1997), fungi (Breeuwer et al. 1995, Schading et al. 1995) and natural bacterial assemblages (Chrzanowski et al. 1984, Porter et al. 1995, Yamaguchi \& Nasu 1997). The artificial fluorogenic enzyme substrates were fluorescein diacetate or derivatives with a higher cell retention (Dive et al. 1988, Breeuwer et al. 1995, Haugland 2001).

Other features of damaged or dead cells are the absence of a bacterial capsular envelope (Heissenberger et al. 1996), the lack of a nucleoid in the socalled 'ghosts' (Zweifel \& Hagström 1995), a very low ribosome content making the cells undetectable by fluorescence in situ hybridisation (FISH) (Williams et al. 1998, Glöckner et al. 1999), or the inability to incorporate nutrients or organic compounds as visualised by autoradiography (e.g. Meyer-Reil 1978).

The use of fluorescent viability markers for bacteria is well established for bacterial cultures, especially in combination with a flow cytometer. However, there are some difficulties in their adaptation to natural bacteria, which are often much smaller than culture isolates. Bacteria in or on particles and aggregates are often covered by mucus, which restricts or slows down substrate transport to the organisms. This requires a careful adaptation and supervision of methodological protocols. Therefore, we investigated microscopically the percentage of viable bacteria by applying different types of fluorescent viability markers to natural bacterioplankton from different waters. We choose 3 types of microbial activity to characterise viable cells: (1) cell-specific respiration measured by CTC reduction (Rodriguez et al. 1992); (2) membrane integrity investigated with 3 different 'dead cell' stains (Haugland 2001); and (3) the cellular enzyme activity by measuring esterase-active (Chrzanowski et al. 1984) and peptidase-active bacteria (Haugland 2001). Samples of natural pelagic bacteria were taken from 12 stations with different salinities and very contrasting concentrations of dissolved (DOC) and particulate organic matter (POC). All stations were sampled twice: first during winter at water temperatures $<5^{\circ} \mathrm{C}$ and then at the onset of the phytoplankton spring bloom when water temperatures were higher but there were still enough inorganic nutrients (Schumann et al. 2003, this issue).

A main aim of this work was to find out whether or not 3 viability stain types sensitive to different physiological processes result in the same portion of active or intact bacteria. We wanted to check in further detail if 3 different impermeant nucleic acid stains, the socalled 'dead cell' stains, would label the same portions of bacteria with damaged membranes. We considered this to be unlikely because molecules of different size and charge may penetrate bacteria depending on the species as well as the type and extent of membrane damage. Additionally, we intended to show the range and variability of the portion of metabolically active and intact bacteria in natural water samples. The influence of environmental factors (i.e. salinity, organic matter and temperature) and the bacterial production on the fraction of active and intact bacteria was be estimated from correlation analyses. The results presented here will form the basis for further experiments.

\section{MATERIALS AND METHODS}

Sampling. To obtain information from different pelagic systems, 3 freshwater, 5 estuarine and 4 coastal stations of the southern Baltic Sea were sampled once in winter at water temperatures below $5^{\circ} \mathrm{C}$ and once during spring (Schumann et al. 2003). From the upper $50 \mathrm{~cm}, 10 \mathrm{l}$ samples were taken and transported in a cold box to the laboratory within $1 \mathrm{~h}$. They were then incubated for activity measurements and processed immediately for all other determinations. Samples were kept at in situ temperature for all viability staining and counting procedures, which were performed within the next $7 \mathrm{~h}$ (Fig. 1). Methods to determine POC and DOC, the $\mathrm{C} / \mathrm{N}$ ratio, chlorophyll a (chl a) concentration, bacterial production and hydrolytic enzyme activities are presented in Schumann et al. (2003). 




Fig. 1. Sample incubations. Excitation (Ex) and name of filter cubes for Olympus BH2-RFCA are in parentheses: UV (UG-1), blue (BP 490) and green (BP 545) light. The emitted fluorescence colour (Em), fluorescent stains (SYTOX $=\mathrm{SYTOX}^{\circledR}$ Green, Eth-D2 $=$ Ethidium homodimer-2, LIVE/DEAD $=$ LIVE/DEAD ${ }^{\circledR}$ BacLight ${ }^{\mathrm{TM}}$ bacterial viability kit including PI = propidium iodide and SYTO 9, DAPI = 4', 6-diamidino-2-phenylindole dihydrochloride, CTC = cyanoditolyltetrazolium chloride, CMFDA = 5-chloromethylfluorescein diacetate or CellTrackerTM Green, CMAC-Leu $=7$-amino-4-chloromethylcoumarin, L-leucine amide, hydrochloride) and the resulting bacterial abundances grouped into intact, respiring, hydrolytically active and total cell counts are also indicated

Bacterial abundance. Total bacterial cell numbers were counted in unfixed samples after staining with DAPI (Roth) according to Porter \& Feig (1980). Replicate subsamples of 0.5 to $2.0 \mathrm{ml}$ were filtered onto black stained $0.2 \mu \mathrm{m}$ Isopore ${ }^{\mathrm{TM}}$ polycarbonate filters (Sigma-Aldrich) and stained separately (1 mg DAPI in $100 \mathrm{ml}$ phosphate buffer $\mathrm{pH}$ 7.6, $29 \mu \mathrm{M}$ final concentration) for $10 \mathrm{~min}$. DAPI stained cells always served as the reference to calculate percentages of active or damaged cells.

The total cell number resulting from the application of the LIVE/DEAD ${ }^{\circledR}$ BacLight ${ }^{\mathrm{TM}}$ bacterial viability kit (Molecular Probes Europe) was calculated in order to check its correspondence with the DAPI counts.

All bacteria were counted under an Olympus BH2RFCA at a 1250 -fold magnification with the filter sets UG-1 for UV excited blue, BP 490 for blue excited yellow-green and BP 545 for green excited red fluorescence. The staining procedures were carried out according to the product information sheets provided by the manufacturers. Four replicate filters and 500 bacteria for dual and 400 cells for single staining procedures were always counted. The BacLight mounting oil, which is part of the viability kit (see next subsec- tion), was also used for the other 'dead cell' stains because standard immersion oils may permeabilise cells on the filter. For all other stains, immersion oil (Olympus) was used as the embedding medium.

Membrane integrity. Three different membrane impermeant fluorescent stains were applied to test the membrane integrity of bacteria. All of these are nucleic acid-specific stains, which are larger than cell permeant fluorescent markers, are often charged, and/or have groups that cause steric hindrance for membrane diffusion. The first stain we applied was propidium iodide (PI), which is a doubly charged phenanthridinium derivative. It was used by Williams et al. (1995) for detritus and then in 1998 as a 'dead cell' stain for aquatic bacteria, and is actually one of the most common stains for dead cells (Haugland 2001). We applied PI as part of the LIVE/DEAD ${ }^{\circledR}$ BacLight $^{\mathrm{TM}}$ bacterial viability kit together with the permeant SYTO 9. Under blue excitation, intact cells appear green due to SYTO 9 staining and permeabilised cells appear red because of additional or replacement intercalation by PI into the nucleic acids (Boulos et al. 1999). We applied PI as part of the viability kit according to the manufacturer's instructions at a final concentration of $3.3 \mathrm{mM}$. 
As the second membrane impermeant stain, we used the asymmetrical, triply charged cyanine dye SYTOX ${ }^{\circledR}$ Green (Molecular Probes Europe) (Roth et al. 1997). The final concentration for staining was $0.5 \mu \mathrm{M}$ as proposed on the product information sheet.

Ethidium homodimer-2 (Eth-D2) (Molecular Probes Europe), which is also as 'Dead Red' part of a viability kit (LIVE/DEAD ${ }^{\circledR}$ reduced biohazard cell viability kit \#1), consists of 2 phenanthridinium fluorophores with a large spacer group and is quadruply charged. Eth-D2 was applied, like SYTOX, at a final concentration of $0.5 \mu \mathrm{M}$.

Because differences in the membrane permeability of the 3 stains were observed, we defined the portion of permeabilised cells as the maximum number of bacteria that could be stained by any of the impermeant stains.

Respiring bacteria. The reduction of CTC to red fluorescing formazan crystals via electron transport activity was used to detect respiring bacteria (Rodriguez et al. 1992). Incubation times $>6 \mathrm{~h}$ at in situ temperature and $5 \mathrm{mM}$ CTC resulted in the highest numbers of active bacteria, which could not be enhanced by further prolongation of incubation time or substrate concentration. Bacteria were counter-stained with DAPI (see above) and 500 of them were examined for fluorescing crystals.

Hydrolytically active bacteria. 5-chloromethylfluorescein diacetate (CellTracker ${ }^{\mathrm{TM}}$ Green CMFDA, Molecular Probes Europe) was applied as an artificial substrate for esterases. After enzymatical hydrolysis, CMFDA starts to fluoresce and is bound by its chloromethyl-group to the intracellular protein pool (Haugland 2001). Thus, cells with esterase activity are stained.

To stain peptidase-active bacteria, 7-amino-4-chloromethylcoumarin, L-leucine amide, hydrochloride (CMAC-Leu, Molecular Probes Europe) was used in the same way. Stock solutions of $5 \mathrm{mM}$ artificial substrate in $100 \%$ dimethyl sulfoxide were prepared and stored at $-20^{\circ} \mathrm{C}$ for up to $3 \mathrm{wk}$. All samples were incubated at final concentrations of $91 \mu \mathrm{M}$ and in situ temperatures for $>5 \mathrm{~h}_{\text {; }}$ analogous to the quantitative enzyme assays.

Some fluorescent stains, e.g. the fluorescent breakdown products of CMFDA or CTC, faded very quickly. Although it was always possible to count bacteria, we had to apply anti-fading substances in the preparation of samples for microphotography. Propylgallate at trace concentrations was especially effective.

Statistical analysis. Differences between bacterial numbers stained by different dyes in the same sample were detected by $t$-test. If the data did not pass a normality and equal variance test, the Mann-Whitney rank sum test was applied. The all-pairwise, multiple comparison Student-Newman-Keuls method or Dunn's test were used to isolate significantly differing values when more than 2 stains were compared. To compare the mean cell numbers stainable by 2 dyes in all samples together, a 1-way ANOVA was used for data passing the normality and equal variance test. Otherwise, the Kruskal-Wallis 1-way analysis on ranks was chosen. A critical p-value of $<0.05$ was always applied.

\section{RESULTS}

\section{Characterisation of the sampling stations}

The description of sampling stations and times is given in Schumann et al. (2003) along with organic matter, microbial abundances and activities. Here, we summarise the ranges of organic matter and bacterial cell numbers, and classify the freshwater, estuarine and Baltic Sea samples concerning their trophy.

Two of the 3 freshwater sites were classified as eutrophic. The deepest lake, Tiefer See (TS), was ranked as mesotrophic. Maximum POC concentrations, bacterial abundances and production were $1.6 \mathrm{mg} \mathrm{Cl}^{-1}, 11 \times 10^{6}$ bacteria $\mathrm{ml}^{-1}$ and $4.4 \mu \mathrm{g} \mathrm{Cl}^{-1} \mathrm{~h}^{-1}$, respectively. These values were lower than those from estuarine sites, but much higher than the Baltic Sea coastal stations. In contrast, DOC concentrations were as high as in the estuarine stations $\left(\leq 12 \mathrm{mg} \mathrm{C}^{-1}\right)$.

The estuarine waters are semi-enclosed, shallow, highly productive systems and dominate the southern Baltic Sea coast line. Due to strong eutrophication until the early 1990s, high amounts of POC and DOC accumulated in these waters. Concentrations of POC $\leq 16$

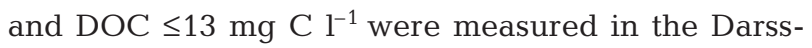
Zingst bodden chain. Bacterial abundances and activities were rather high with a maximum of $24 \times 10^{6} \mathrm{ml}^{-1}$ and $18 \mu \mathrm{g} \mathrm{C}^{-1} \mathrm{~h}^{-1}$. The other estuarine station (Unterwarnow, UW), being the estuary of the river Oberwarnow $(\mathrm{OW})$, has a more intensive water exchange with the Baltic Sea and therefore, a lower organic burden and fewer bacteria $\left(\leq 1.8 \mathrm{mg} \mathrm{POC}^{-1}, \leq 9.8 \mathrm{mg}\right.$ DOC $\mathrm{l}^{-1}, \leq 14 \times 10^{6}$ bacteria $\mathrm{ml}^{-1}$ ).

The coastal stations of the Baltic Sea, classified as mesotrophic, were not severely loaded with organic matter and bacteria (POC $\leq 0.8, \mathrm{DOC} \leq 5.5 \mathrm{mg} \mathrm{Cl}^{-1}$, bacteria $\leq 3 \times 10^{6} \mathrm{ml}^{-1}$ ), although they are rather shallow and sediment particles were included sometimes in the samples. Bacterial production was on average much lower than at all other stations, but 1 high rate of $4.6 \mu \mathrm{g} \mathrm{C}$ $\mathrm{l}^{-1} \mathrm{~h}^{-1}$ approached those seen in freshwater systems. This particular sample was taken during stormy weather and contained resuspended sediment particles.

Spring bacterial abundances were up to 2.8 times higher compared to winter data at the fresh and brackish water stations. In contrast, bacterial cell numbers in the Baltic Sea decreased by at least $32 \%$. 


\section{Bacteria with permeable membranes}

In the freshwater samples, intermediate bacterial cell numbers were observed. Highest values occurred at the estuarine stations. The Baltic Sea samples always had the lowest bacterial numbers. Their abundances were at least 1.6 times lower than in any other sample (Fig. 2).

Compared to the DAPI-stainable bacteria, we observed only $60 \%$ (33\% at lowest) of them with the LIVE/DEAD ${ }^{\circledR}$ BacLight ${ }^{\mathrm{TM}}$ bacterial viability kit as the sum of living and dead bacteria. In 16 out of 24 investi-

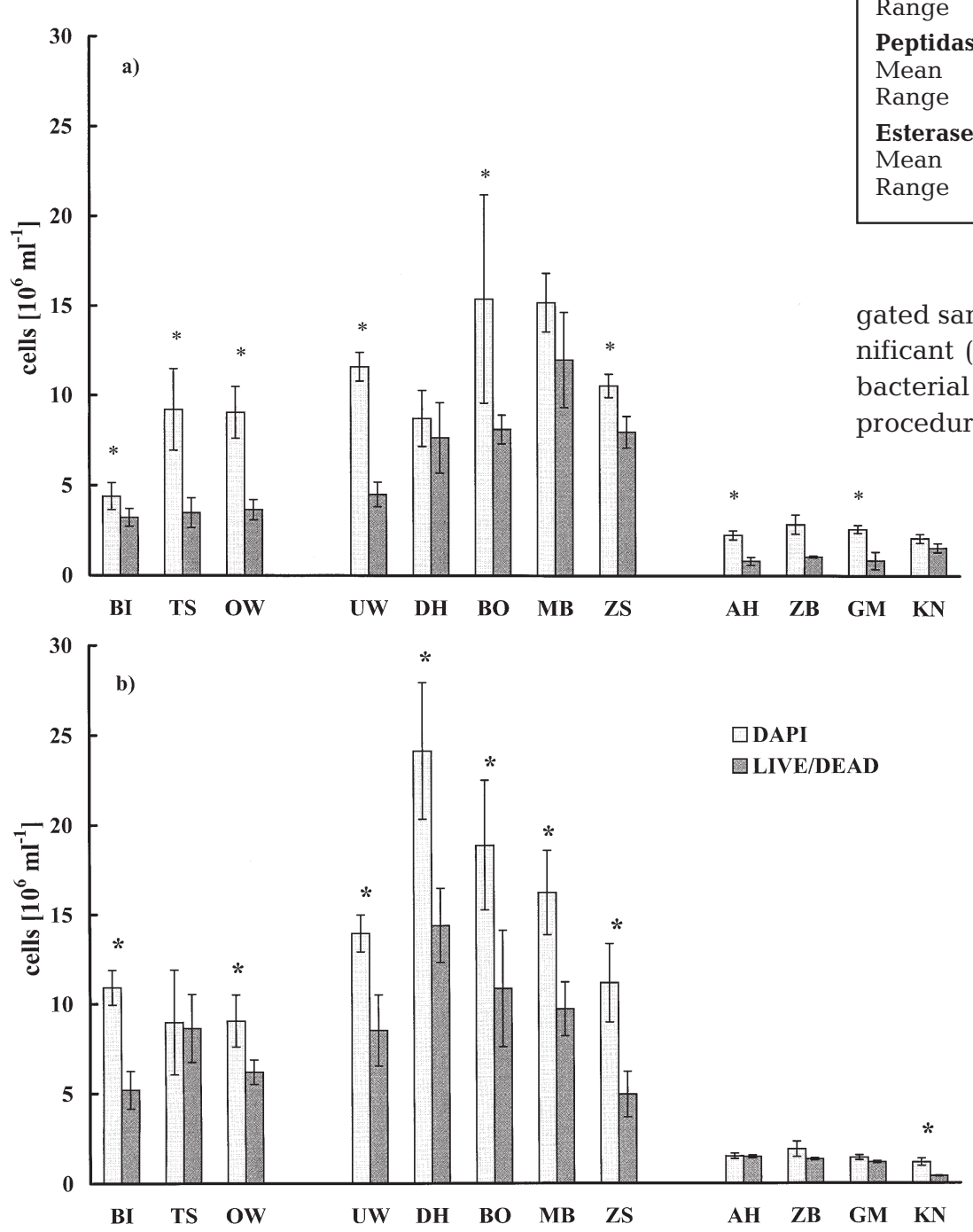

Fig. 2. Total bacterial abundances $\left(10^{6} \mathrm{ml}^{-1}\right)$ counted after DAPI staining and added up from living and dead bacteria marked by the LIVE/DEAD ${ }^{\circledR}$ BacLight ${ }^{\mathrm{TM}}$ bacterial viability kit. Error bars represent \pm SD of 4 replicates and $*$ marks significantly different results of both staining procedures with a critical $p$-value of $<0.05$. Freshwater locations are Biestower Dorfteich (BI), Tiefer See (TS) and Oberwarnow (OW). Estuarine stations are Unterwarnow (UW), Dierhagen (DH), Born (BO), Müggenburg (MB) and Zingster Strom (ZS). Baltic Sea sites are Ahrenshoop (AH), Zingster Seebrücke (ZB), Graal-Müritzer Seebrücke (GM) and Kühlungsborner Seebrücke (KN). For station locations see also Fig. 1 in Schumann et al. (2003)
Table 1. Percentage of bacteria with impermeable (intact) membranes (DAPI minus the highest number of bacteria counted by any of the 3 impermeant dead cell stains [PI, Eth-D2 or SYTOX]), respiratory activity (CTC-positive), peptidase activity (CMAC-Leu-positive) and esterase activity (CMFDA-positive) averaged for the different water systems and sampling periods

\begin{tabular}{|lccccc|}
\hline Bacteria with: & $\begin{array}{c}\text { Fresh- } \\
\text { water }\end{array}$ & Estuaries & $\begin{array}{c}\text { Baltic } \\
\text { Sea }\end{array}$ & Winter & Spring \\
\hline $\begin{array}{l}\text { Intact membranes } \\
\text { Mean }\end{array}$ & 61 & 64 & 55 & 65 & 56 \\
$\begin{array}{l}\text { Range } \\
\text { Respiratory activity }\end{array}$ & 10 & 10 & 14 & 14 & 9 \\
$\begin{array}{l}\text { Mean } \\
\text { Range }\end{array}$ & $(1-21)$ & $(3-23)$ & $(3-48)$ & $(3-48)$ & $(1-21)$ \\
$\begin{array}{l}\text { Peptidase activity } \\
\text { Mean }\end{array}$ & 6 & 5 & 3 & & $(38-79)$ \\
$\begin{array}{l}\text { Range } \\
\text { Esterase activity } \\
\text { Mean }\end{array}$ & $(1-20)$ & $(1-11)$ & $(1-5)$ & $(1-20)$ & $(1-7)$ \\
Range & 9 & 12 & 5 & 8 & 10 \\
& $(3-15)$ & $(2-24)$ & $(3-11)$ & $(3-24)$ & $(4-20)$ \\
\hline
\end{tabular}

ated samples, these differences were statistically sigificant (Fig. 2). Nevertheless, we always refer to the acterial abundance resulting from the DAPI staining , because it is one of the most often applied nucleic acid stains in bacteria enumeration protocols.

In the freshwater samples, permeabilised cells varied between 2.1 and $5.2 \times 10^{6}$ $\mathrm{ml}^{-1}$, at the estuarine stations between 3.5 and $8.1 \times 10^{6} \mathrm{ml}^{-1}$ and reached only $1.3 \times$ $10^{6} \mathrm{ml}^{-1}$ in the Baltic (Fig. 3). Their percentage of total abundance accounted for 39,36 and $45 \%$ on average, respectively (Table 1). In 14 samples, PI stained significantly more cells than SYTOX, and in 19 samples, more cells than Eth-D2. The only 4 samples of significantly more SYTOXpositive than PI-positive cells were all of estuarine origin. Only in 3 samples, all of them from the Baltic Sea, were there significantly more Eth-D2-positive than SYTOX-positive. Eth-D2 stainable cell numbers never exceeded PI-marked ones significantly (Fig. 3).

The average percentages of permeabilised cells increased from winter to spring from 35 to $44 \%$ (cf. Table 1). Hence, 32 and $36 \%$ were detected by PI, 17 and $27 \%$ by SYTOX and 8 and $18 \%$ by Eth-D 2 in the winter and spring sampling period, respectively. This was not simply the result of lowered total numbers (Fig. 2), but was due to an increase in absolute numbers of permeabilised cells (Fig. 3). 


\section{Respiring bacteria}

Formazan crystals resulting from respiratory activity could be observed in $10 \%$ (1 to $23 \%$ ) of the bacteria from freshwater and estuarine samples. In the Baltic Sea water samples, this average percentage was slightly higher with $14 \%$ (3 to $48 \%$ ) (Table 1). Differences between seasons were insignificant.

\section{Hydrolytically active bacteria}

Peptidase-positive cells were not only rare, but cellular peptidase seems to be specific for large and striking (Fig. 4a) or algae-associated cells (Fig. 4b). The fluo-
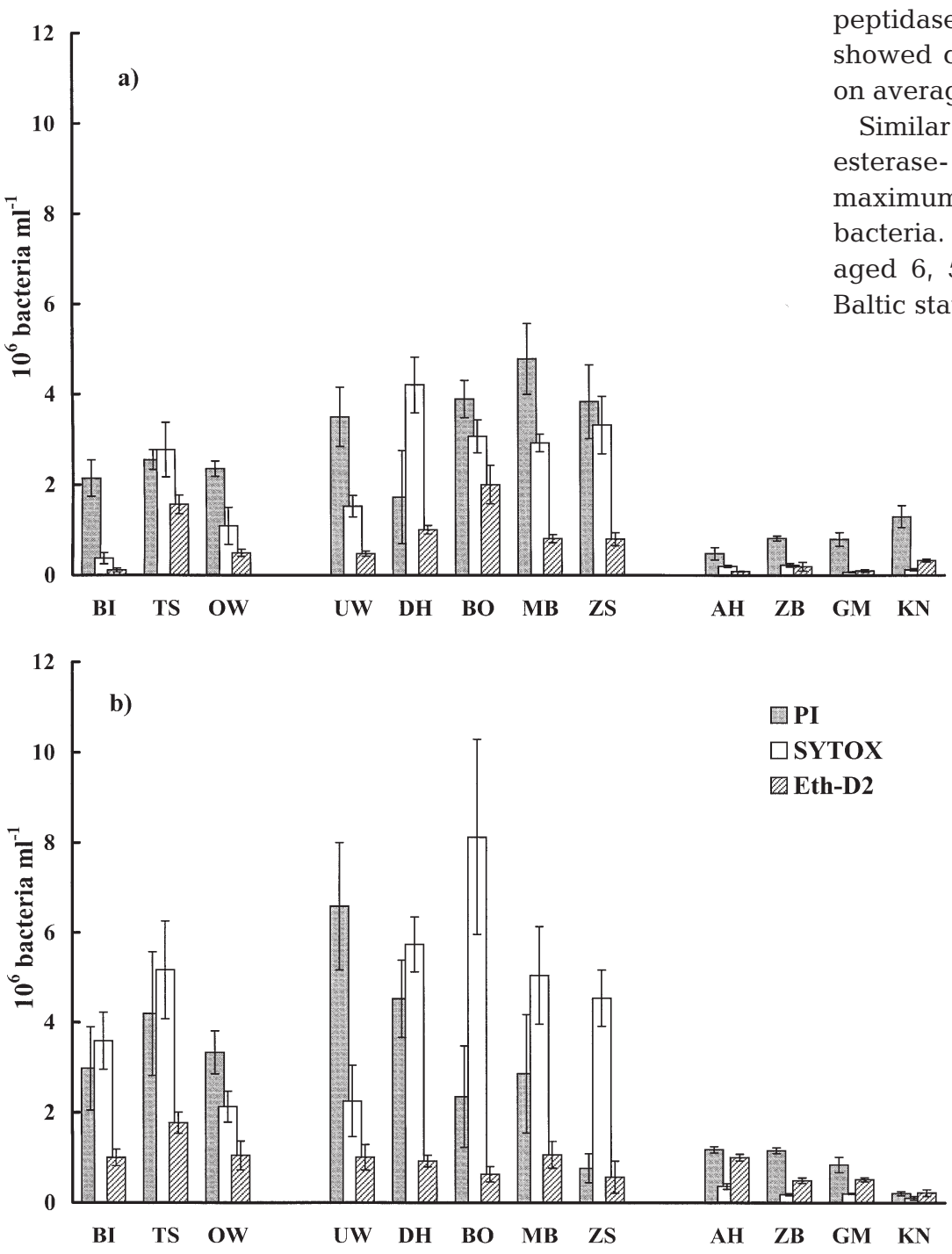

Fig. 3. Permeabilised (=morphologically not intact) cells $\left(10^{6} \mathrm{ml}^{-1}\right)$ detected by propidium iodide (PI), SYTOX ${ }^{\circledR}$ Green and ethidium homodimer-2 (Eth-D2). Error bars represent \pm SD of 4 replicates. For station names see Fig. 2 and locations see Fig. 1 in Schumann et al. (2003) rescence brightness was sufficient, but compared to DAPI (Fig. 4c), which has a ca. 30 times enhanced fluorescence upon binding to nucleic acids, it was rather dim. Cellular esterase is obviously more related to slightly larger bacteria (Fig. 4d). The chloromethylfluorescein-labelled cells were brightly fluorescent, but they quickly faded, and therefore required a considerable reduction of excitation light.

Up to $1.82 \times 10^{6}$ peptidase and $1.32 \times 10^{6}$ esteraseactive bacteria were found in freshwater per $\mathrm{ml}$ and up to $1.38 \times 10^{6}$ and $2.95 \times 10^{6}$ peptidase and esterasepositive cells were counted in estuarine samples per ml (Fig. 5). In the Baltic Sea samples, the highest observed number of hydrolytically active bacteria was only $0.16 \times 10^{6} \mathrm{ml}^{-1}$. In 19 out of the 24 samples, there were significantly more esterase-positive bacteria than peptidase-active. About 4 times as many bacteria ed cell bound esterase activity in these samples Similar to th maximum of 24 and $20 \%$ of all DAPI-stainable The portion of peptidase-active cells averged 6,5 and $3 \%$ in the freshwater, estuarine and , respectively. Esterase-positive cells accounted for an average of 9,12 and 5 of the total bacterial abundance, respectively (Table 1).

Significant differences between winter and spring samples could not be detected for the percentage of hydrolytically active bacteria (Table 1). However, especially in estuarine waters, the absolute number of esterase-positive cells were higher in spring, significantly at 3 of the 5 stations. Peptidase-positive cells of these stations were higher in winter than in spring (Fig. 5).

\section{Physiological states of individual cells depending on environmental conditions}

Although we sampled waters with different salinities, we could not detect strong dependencies of bacterial activities, cell numbers or the percentage of active or intact bacteria from this abiotic factor by correlation analysis. Nor could a relationship to water temperature be established (Table 2), because we sampled only at rather low temperatures in winter and low to moderate temperatures in spring (Schumann et al. 2003). 

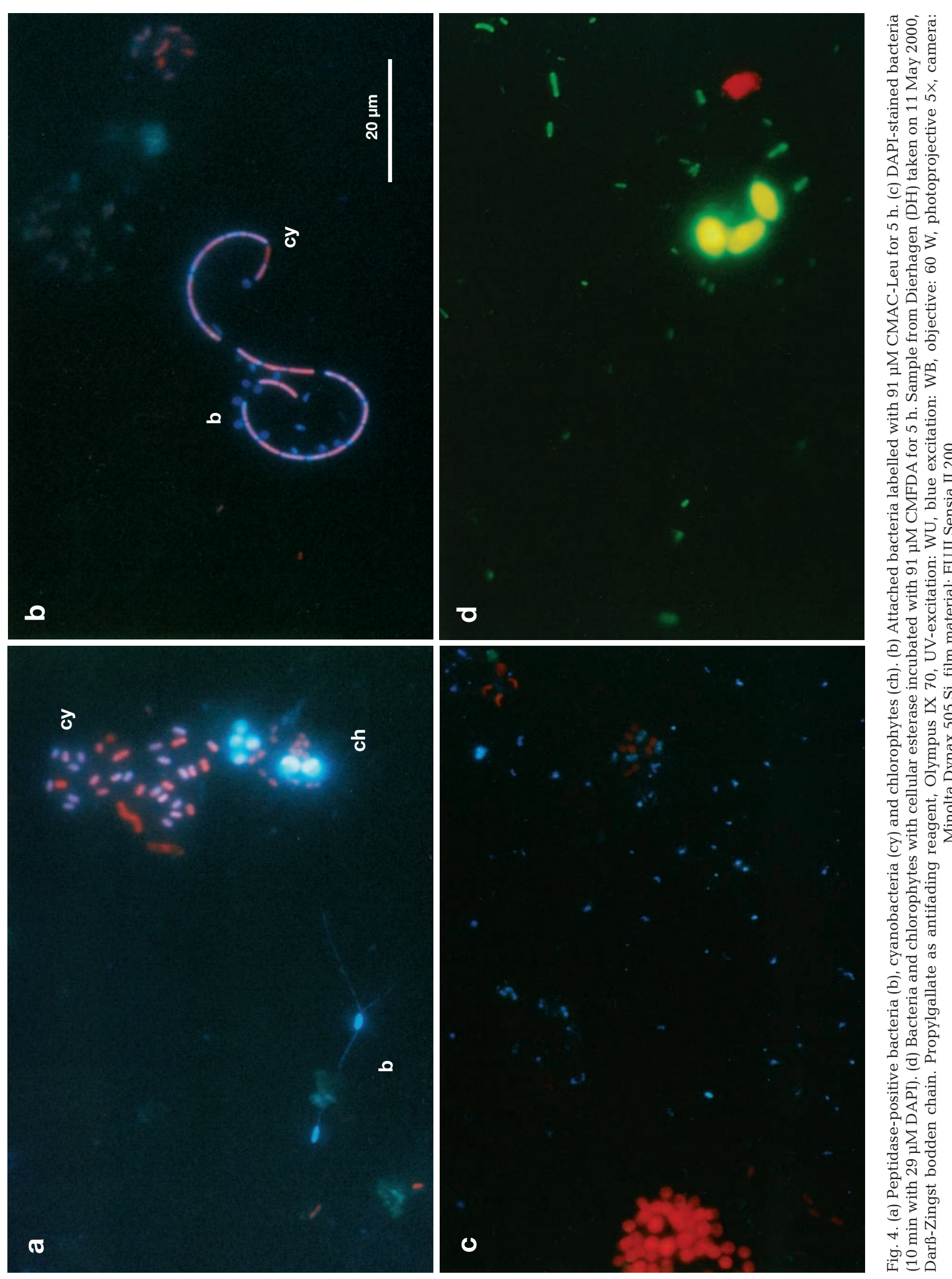


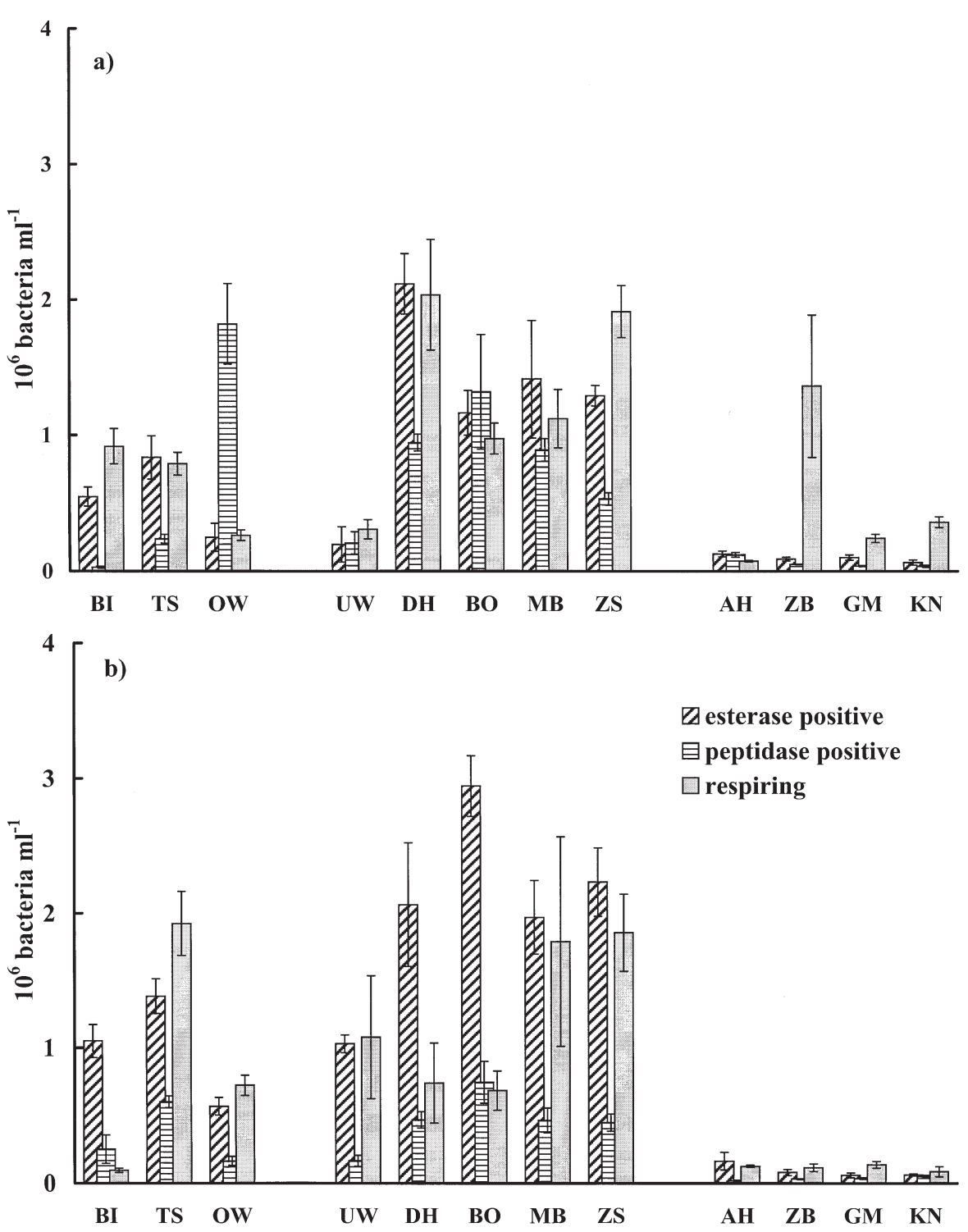

Fig. 5. Bacteria with cellular esterase stained by CMFDA, with peptidase by CMACLeu and respiring cells marked by formazan crystals (CTC-positive) $\left(10^{6} \mathrm{ml}^{-1}\right)$ at all stations in (a) winter and (b) spring. Error bars represent \pm SD of 4 replicates. For station names and arrangement see Fig. 2

and especially on phytoplankton exudation, it is impossible to evaluate whether the activities were causally related to phytoplankton, an altered organic matter supply by different primary production rates or only an indirect correlation via the co-occurrence of bacteria and phytoplankton.

Bacterial activities, production and hydrolytic activity were strongly correlated with organic matter concentrations (Schumann et al. 2003). Bacterial abundance and the numbers of intact and active cells themselves also increased significantly with bacterial activity. Surprisingly, respiring bacteria were not correlated with production measured by leucine uptake and respiration. However, the percentage of intact and active cells did not correlate with bacterial activity, except for esterase-positive cells and hydrolytic activity (Table 3).

\section{DISCUSSION}

\section{Viability test parameters}

The first prerequisite of viability is the presence of DNA and RNA in the cells, which can be visualised by nucleic acid-specific stains, like DAPI, even in viable but not culturable cells (VBNC) (Weichart et al. 1997). If oligonucleotide probes hybridise to enough binding sites in cells, one can assume that the rRNA level is high and the cell can be declared as living and active. In combination with impermeant nucleic acid staining, several cell states between living and

However, bacterial abundance depended strongly on organic matter concentrations (Table 2; Schumann et al. 2003). The number of intact and active cells always increased significantly with organic matter. The $r_{S}$-values of the correlation between respiring bacteria and organic matter were the lowest. Only the percentage of esterase-positive bacteria increased with organic matter concentrations. No other percentages of intact or active cells correlated with organic matter (Table 2).

There were also strong correlations of total, intact and active bacterial cell numbers to the chl a concentration. However, without data on primary production dead can be described, e.g. inactive but living (Williams et al. 1998).

Most of the comparisons between different viability states were obtained from antibiotic susceptibility experiments or tests of other stress factors, e.g. UV radiation, starvation, heavy metals and coldness. If the fluorescent probe detects viable cells that are dividing, the results from the fluorescent marked cells have to relate to the plate or direct viable counting methods. Membrane permeability, tested by the staining of cells with impermeant nucleic acid stains after antibioticinduced cell damage, reflected injury of Escherichia coli, but the results were not confirmed by the plate 
Table 2. Spearman rank order correlation between water temperature $\left(T_{\mathrm{W}}\right)\left({ }^{\circ} \mathrm{C}\right)$, salinity (psu), particulate organic carbon $(\mathrm{POC})$

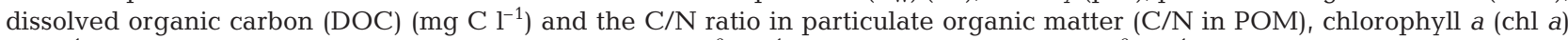
$\left(\mu \mathrm{g} \mathrm{l}^{-1}\right)$, total bacterial abundance after DAPI staining $\left(10^{6} \mathrm{ml}^{-1}\right)$ versus the abundance $\left(10^{6} \mathrm{ml}^{-1}\right)$ and the percentage of impermeable, respiring, peptidase-positive and esterase-positive bacteria (\%). $\mathrm{r}_{\mathrm{S}}$ : correlation coefficient; $\mathrm{p}$ : error probability; ${ }^{*}$ : significantly correlated with $\mathrm{p}<0.05 ; \mathrm{n}=24$, except for respiration, where $\mathrm{n}=21$

\begin{tabular}{|c|c|c|c|c|c|c|c|c|c|}
\hline & \multirow{2}{*}{$\begin{array}{c}\text { Abundance } \\
\text { Total }\end{array}$} & \multicolumn{4}{|c|}{ Abundance of intact or active cells } & \multicolumn{4}{|c|}{ Percentage of intact or active cells } \\
\hline & & Impermeable & Respiring & Peptidase + & Esterase + & Impermeable & Respiring & Peptidase + & Esterase + \\
\hline \multicolumn{10}{|c|}{$T_{\mathrm{W}}$} \\
\hline$r_{S}$ & 0.12 & 0.01 & -0.09 & -0.12 & 0.24 & $-0.43^{*}$ & -0.10 & -0.22 & 0.37 \\
\hline $\mathrm{p}$ & 0.59 & 0.95 & 0.68 & 0.60 & 0.27 & 0.04 & 0.64 & 0.31 & 0.09 \\
\hline \multicolumn{10}{|c|}{ Salinity } \\
\hline$r_{S}$ & $-0.48^{*}$ & -0.51 & -0.27 & $-0.49^{*}$ & $-0.52^{*}$ & -0.09 & 0.20 & -0.25 & -0.39 \\
\hline $\mathrm{p}$ & 0.02 & 0.01 & 0.20 & 0.01 & 0.01 & 0.69 & 0.34 & 0.23 & 0.06 \\
\hline \multicolumn{10}{|c|}{ POC } \\
\hline $\mathrm{r}_{\mathrm{S}}$ & $0.84^{*}$ & $0.79^{*}$ & $0.56^{*}$ & $0.66^{*}$ & $0.89^{*}$ & 0.18 & -0.10 & 0.33 & $0.57^{*}$ \\
\hline $\mathrm{p}$ & 0 & 0 & 0 & 0 & 0 & 0.38 & 0.65 & 0.11 & 0 \\
\hline \multicolumn{10}{|c|}{ DOC } \\
\hline$r_{S}$ & $0.71^{*}$ & $0.72^{*}$ & $0.58^{*}$ & $0.70^{*}$ & $0.79^{*}$ & 0.10 & -0.00 & 0.40 & $0.48^{*}$ \\
\hline $\mathrm{p}$ & 0 & 0 & 0 & 0 & 0 & 0.65 & 0.98 & 0.05 & 0.02 \\
\hline \multicolumn{10}{|c|}{$\mathrm{CN}$ in $\mathrm{POM}$} \\
\hline $\mathrm{r}_{\mathrm{S}}$ & 0.07 & 0.04 & -0.04 & -0.03 & 0.18 & 0.21 & 0.01 & 0.06 & 0.25 \\
\hline $\mathrm{p}$ & 0.74 & 0.84 & 0.84 & 0.89 & 0.41 & 0.31 & 0.98 & 0.78 & 0.23 \\
\hline \multicolumn{10}{|c|}{ Chl a } \\
\hline $\mathrm{r}_{\mathrm{S}}$ & $0.73^{*}$ & $0.74^{*}$ & $0.45^{*}$ & $0.61^{*}$ & $0.77^{*}$ & 0.12 & -0.12 & 0.35 & $0.53^{*}$ \\
\hline $\mathrm{p}$ & 0 & 0 & 0.03 & 0 & 0 & 0.56 & 0.58 & 0.09 & 0.01 \\
\hline \multicolumn{10}{|c|}{ Bacterial abundance } \\
\hline $\mathrm{r}_{\mathrm{S}}$ & - & $0.98^{*}$ & $0.47^{*}$ & $0.72^{*}$ & $0.81^{*}$ & 0.29 & -0.31 & 0.23 & 0.35 \\
\hline $\mathrm{p}$ & & 0 & 0.02 & 0 & 0 & 0.17 & 0.14 & 0.28 & 0.09 \\
\hline
\end{tabular}

Table 3. Spearman rank order correlation between bacterial production measured by leucine and thymidine uptake $\left(\mu \mathrm{C} \mathrm{C} \mathrm{l}^{-1} \mathrm{~d}^{-1}\right)$,

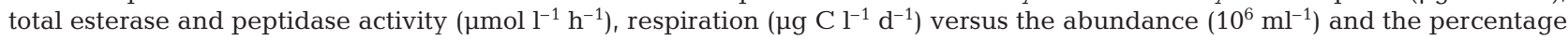
of impermeable, respiring, peptidase-positive and esterase-positive bacteria (\%). $\mathrm{r}_{\mathrm{S}}$ : correlation coefficient; $\mathrm{p}$ : error probability;

${ }^{*}$ : significantly correlated with $\mathrm{p}<0.05 ; \mathrm{n}=24$, except for respiration, where $\mathrm{n}=21$

\begin{tabular}{|c|c|c|c|c|c|c|c|c|c|}
\hline & \multirow{2}{*}{$\begin{array}{c}\text { Abundance } \\
\text { Total }\end{array}$} & \multicolumn{4}{|c|}{ Abundance of intact or active cells } & \multicolumn{4}{|c|}{ Percentage of intact or active cells } \\
\hline & & Impermeable & Respiring & Peptidase + & Esterase + & Impermeable & Respiring & Peptidase + & Esterase + \\
\hline \multicolumn{10}{|c|}{ Production (leucine) } \\
\hline $\mathrm{r}_{\mathrm{S}}$ & $0.63^{*}$ & $0.65^{*}$ & 0.02 & $0.49^{*}$ & $0.59^{*}$ & 0.30 & $-0.49^{*}$ & 0.30 & 0.39 \\
\hline $\mathrm{p}$ & 0 & 0 & 0.91 & 0.02 & 0 & 0.15 & 0.02 & 0.15 & 0.06 \\
\hline \multicolumn{10}{|c|}{ Production (thymidine) } \\
\hline $\mathrm{r}_{\mathrm{S}}$ & $0.48^{*}$ & $0.66^{*}$ & $0.54^{*}$ & $0.53^{*}$ & $0.61^{*}$ & 0.31 & -0.01 & 0.28 & 0.30 \\
\hline $\mathrm{p}$ & 0.02 & 0 & 0.01 & 0.01 & 0 & 0.14 & 0.95 & 0.19 & 0.15 \\
\hline \multicolumn{10}{|c|}{ Total esterase activity } \\
\hline$r_{S}$ & $0.80^{*}$ & $0.77^{*}$ & $0.61^{*}$ & $0.68^{*}$ & $0.89^{*}$ & 0.11 & 0.03 & 0.36 & $0.66^{*}$ \\
\hline $\mathrm{p}$ & 0 & 0 & 0 & 0 & 0 & 0.60 & 0.90 & 0.08 & 0 \\
\hline \multicolumn{10}{|c|}{ Total peptidase activity } \\
\hline $\mathrm{r}_{\mathrm{S}}$ & $0.80^{*}$ & $0.77^{*}$ & $0.55^{*}$ & $0.66^{*}$ & $0.90^{*}$ & -0.01 & -0.08 & 0.34 & $0.68^{*}$ \\
\hline $\mathrm{p}$ & 0 & 0 & 0.01 & 0 & 0 & 0.96 & 0.69 & 0.10 & 0 \\
\hline \multicolumn{10}{|c|}{ Respiration } \\
\hline$r_{S}$ & $0.77^{*}$ & $0.78^{*}$ & 0.37 & $0.65^{*}$ & $0.64^{*}$ & 0.43 & -0.26 & 0.39 & 0.25 \\
\hline $\mathrm{p}$ & 0 & 0 & 0.09 & 0 & 0 & 0.05 & 0.24 & 0.08 & 0.27 \\
\hline
\end{tabular}

counting method (Mortimer et al. 2000). The same was found for copper-killed, plant-associated bacteria (Alexander et al. 1999) or starved Salmonella typhimurum (Caro et al. 1999). Trans-membrane potential and respiratory activity seem to be more sensitive characteristics of viable cells than membrane permeability, especially in stressed cells (Jepras et al. 1997, Boulos et al. 1999, Caro et al. 1999). However, there are other investigations of $E$. coli which demonstrated that the loss of culturability through even moderate doses of UV irradiation was not reflected by any of the measured cellular activities (Fiksdal \& Tryland 1999). Since UV radiation directly affects nucleic acids, its target is specifically and strictly cell division. 
This lack of congruence of certain viability tests requires thorough operational definitions of active and viable bacteria and the appropriate choice of fluorescent markers regarding the goals of the respective investigation. Moreover, for the study of microbial carbon and nitrogen turnover processes in natural environments not only live bacteria with the ability to divide are of interest, but also especially those cells that actually show certain activities, e.g. hydrolysis of polymers.

\section{Permeant and impermeant nucleic acid-specific fluorescent stains}

The systematic underestimation of total bacterial abundance (living + dead cells) by the LIVE/DEAD ${ }^{\circledR}$ BacLight ${ }^{\mathrm{TM}}$ bacterial viability kit was also found by Gasol et al. (1999), who investigated bacteria from Mediterranean coastal waters. In contrast, Lebaron et al. (1998b) reported that SYTO 9, which is part of the viability kit, is most suited for counting living bacteria. Concerning the suitability of DAPI in comparison to the also often used acridine orange, there is evidence for further underestimation of bacterial total counts (Suzuki et al. 1993). However, orange and red fluorescing dyes do not allow a clear differentiation from picocyanobacteria, which are very abundant in the estuarine samples from the Darss-Zingst bodden chain (Klinkenberg \& Schumann 1995) and can be important in other systems.

The application of the different impermeant probes PI, SYTOX and Eth-D2 resulted in decreasing percentages of permeabilised and, hence, not viable bacteria. These differences, which were not depending on the water types sampled, may be the result of a gradual permeabilisation of cells, which allows the permeation of the probes depending on their molecule structure. Thus, Eth-D2 (Haugland 2001) entered only bacteria with completely open membranes. The higher portion of permeabilised cells at higher water temperatures that was detected by all 3 probes may be the result of increased protozoan abundances in spring (Schumann et al. 2003) and their growing grazing pressure, especially on the active fraction (Sherr et al. 1992, del Giorgio et al. 1996).

Other factors that influence the staining of dead cells by impermeant probes were antibiotic and disinfection treatments or starvation, i.e. processes that injure directly or indirectly membranes. The application of SYTOX, PI and TO-PRO-1 to Escherichia coli, injured by a set of antimicrobial treatments acting at different sites, resulted in distinguishable percentages of permeabilised cells. The portion of stained cells seemed to depend on the target process of the antibiotic and dif- ferent efflux rates of the probes (Mortimer et al. 2000), which can be again altered by the cell's energy status and membrane permeability. In contrast to trans-membrane sensitive dyes, PI did not adequately reflect injuries through starvation in 2 bacterial strains (e.g. López-Amorós et al. 1995; cf. discussion above). These facts require a precise knowledge about the bacteria's injury or a strict use of methodological definitions (morphologically intact, culturable, metabolically active) instead of the more theoretical concept of viability (cf. Kell et al. 1998 for a thorough discussion), if impermeant stains are applied to quantify dead cells. However, if the killing agent works directly via membrane lysis, e.g. lytic sera, results with impermeant probes conform with the plate counting method (Virta et al. 1998).

A last drawback of impermeant stains is that they cannot label cells without nucleic acids, which obviously also have to be dead. Thus, a careful estimation of nucleoid-free cells has to be carried out (for a discussion of the 'ghost' problem raised by Zweifel \& Hagström 1995, cf. Choi et al. 1996).

\section{Marker for cellular enzyme activity}

Various fluorescein esters have already been used in bacterial viability assays, e.g. fluorescein diacetate (FDA) (Chrzanowski et al. 1984, Diaper et al. 1992), carboxyfluorescein diacetate (CFDA) (Dive et al. 1988, Miskin et al. 1998) and Chemchrome $B^{\circledR}$ (Clarke \& Pinder 1998). However, in most cases, flow cytometers were applied to count the stained bacteria. Consequently, this technique restricted the investigations to larger and homogeneously distributed cells of bacterial cultures. In the detection of viable eucaryotes, FDA is already widely applied (microalgae: Dorsey et al. 1989, Murphy \& Cowles 1997, Jochem 1999; fungi: Saxena \& Lysek 1993, Schading et al. 1995; pathogenic protozoa: Jackson et al. 1985, Yokoyama et al. 1997). To date, CMFDA has only been used for testing the viability of human cells (Deutsch et al. 2000) and as a vital or cell tracker dye for eucaryotic microbes (Li et al. 1996, Bell et al. 1998).

There seems to be a problem with the permeation of fluorescein diacetate-derivatives into some types of bacteria (Chrzanowski et al. 1984, Jepras et al. 1995). However, the transport of FDA into Saccharomyces cerevisiae was not the limiting step for staining; however, for CFDA, the transport was rather slow (Breeuwer et al. 1995). Because of a lack of data on transport properties of CMFDA, we incubated the samples for more than $5 \mathrm{~h}$ and therefore, much longer than the just-mentioned 3 working groups. By doing so, even at the slow influx rates expected, sufficient 
quantities of the CMFDA esterase substrate should have permeated into all bacteria in order to stain the esterase-active ones.

Another complex of problems arises because of the efflux or loss of the hydrolysis products (Dive et al. 1988). Opposed to fluorescein, chloromethylfluorescein has a high cell retention, because it is bound via glutathion $S$-transferase to the cell's protein pool, and thus stains all esterase-active cells brightly. Carboxyfluorescein has also a much lower efflux velocity than fluorescein in viable cells (Dive et al. 1988), but it can be actively exported by cells (Breeuwer et al. 1994). Thus, esterase-active cells with a good nutrient and energy supply might be less brightly stained than starving cells with a residual esterase activity.

The different percentages of peptidase-active bacteria compared to esterase-active ones as well as the observed different morphotypes (Fig. 4) indicate that (1) esterase substrates are not general viability marker; and (2) there is a potential in such artificial enzyme substrates to localise and assign cell-bound activities to discrete organisms. Unfortunately, the broad emission spectrum of chloromethylfluorescein accompanied by its comparably bright fluorescence leads to false positive results of peptidase-active cells in double staining experiments. Thus, we cannot estimate the proportion of cells with both activities.

\section{Organic matter supply, activity and viability}

In contrast to del Giorgio \& Scarborough (1995) and Sommaruga \& Conde (1997), we could not detect significant correlations between the nutrition of bacteria, expressed as chl $a$ and/or nutrient concentrations, and the portion of respiring bacteria based on our samples (Table 2). Moreover, the abundance and the percentage of respiring cells were not correlated so strongly to abiotic and organic matter parameters as the other viability markers, or even correlated at all. A positive correlation with bacterial production, as was observed by Lovejoy et al. (1996), Sommaruga \& Conde (1997) and Sherr et al. (1999b), could also not be established for any percentage of active cells. However, there were significant positive relationships of organic matter and total hydrolytic enzymes activities with the portion of esterase-positive bacteria, but not with the other percentages of intact or active bacteria (Tables $2 \& 3$ ). The organic matter supply seems not only to increase bacterial cell numbers and activities, but to enlarge specifically the portion of actively organic matterdegrading bacteria. This stimulating effect of organic matter supply could not be proven statistically for intact, respiring or peptidase-positive cells. Although the number of those increased with organic matter and bacterial activities, it seemed to rise only proportionally to the total numbers.

The average percentage of respiring bacteria in our meso- to eutrophic waters (Table 1) was rather low compared to other coastal and freshwater systems, but higher than the data from several oceans (Table 4). Compared to the few data of portions of impermeable bacteria, this percentage was rather high in our systems, at least if we consider the maxima. In contrast to that, the contribution of esterase-positive bacteria to total abundance was more similar to the data from oligotrophic to mesotrophic systems (cf. Tables 1 \& 4). Since there are only few observations of intact and hydrolytically active bacteria (Table 4 ), it would be far too early to draw any ecological conclusions. Moreover, only few investigations of respiring bacteria relate microbial activities to environmental data, e.g. nutrients or biomass other than bacteria (del Giorgio \& Scarborough 1995, Sommaruga \& Conde 1997, Sherr et al. 1999b). Studies of different markers for metabolical activities in the same sample were only done intensively in bacterial cultures (López-Amorós et al. 1995, Jepras et al. 1997, Virta et al. 1998, Boulos et al. 1999, Caro et al. 1999, Fiksdal \& Tryland 1999), but almost never in natural samples (Yamaguchi \& Nasu 1997).

However, the main questions that remain are: Why has the bacterioplankton in the bodden, being loaded heavily with POM and DOM, rather low cell-specific production rates? Why do $40 \%$ (19 to $78 \%$ ) of bacteria from all waters investigated persist in the water column, although their membranes are damaged? Why are they not grazed or degraded? Why do only 10 to $14 \%$ of all bacteria respire if $60 \%$ have intact membranes? DOM, especially in the eutrophic bodden, must be investigated in more detail to estimate if bacteria can be carbon-limited at DOC concentrations of 9 to $13 \mathrm{mg} \mathrm{Cl}^{-1}$.

\section{CONCLUSIONS}

The fluorescent labelling of bacteria, which show special hydrolytic cellular enzyme activities, allows, in combination with a cell-sorting flow cytometer, the subsequent analysis of their genetic diversity and perhaps also their phylogenetic affiliation. Initial results on genetic diversity of respiring (CTC-positive) and viable (nalidixic acid elongated) cells proved that studies on genetic diversity of the total community include nonviable cells (Bernard et al. 2001). The application of probes for special cellular enzymes in such experiments is providing the possibility to relate certain microbial activities to specific taxonomic groups. The combined application of microautoradiographic inves- 
Table 4. Bacterial abundance $\left(10^{6} \mathrm{ml}^{-1}\right)$ and the percentage $(\%)$ of viable and intact cells determined via their respiratory activity (respiring cells visualised by CTC reduction or in italics by iodonitrotetrazolium chloride [INT] reduction), their membrane integrity (intact cells detected by exclusion of impermeant nucleic acid fluorescence markers) and their cellular esterase activity (esterase-positive cells marked fluorescently after enzymatical hydrolysis of fluorogenic esterase substrate analoga). nd: no data available

\begin{tabular}{|c|c|c|c|c|c|c|}
\hline Waters & Characteristics & $\begin{array}{c}\text { Bacterial } \\
\text { abundances }\end{array}$ & \multicolumn{3}{|c|}{ Percentage of viable cells } & Source \\
\hline 24 temperate lakes & & $1.9-7.7$ & $15-33$ & & & del Giorgio \& Scarborough (1995) \\
\hline Lake Rodó & Hypertrophic & $1.5-20.4$ & 47 & & & Sommaruga \& Conde (1997) \\
\hline Lake Geneva & & $0.44-2.6$ & $9-65$ & & & Dufour \& Colon (1992) \\
\hline Virginia groundwaters & & $0.04-0.12$ & $16-21$ & & & King \& Parker (1988) \\
\hline Santa Monica Bay & & $0.49-6.8$ & $<1$ & & & Karner \& Fuhrman (1997) \\
\hline Gulf of St. Lawrence & & $0.23-0.40$ & $<2$ & & & Lovejoy et al. (1996) \\
\hline Pacific coast (Oregon) & & $0.7-2.1$ & $3-19$ & & & Sherr et al. (1999b) \\
\hline Different oceans & & $0.21-0.88$ & $1-6$ & & & Sherr et al. (1999a) \\
\hline Pacific coast (Oregon) & & $0.1-1.3$ & $8-39$ & $9-34$ & & Choi et al. (1996) \\
\hline Mediterranean coast & & $0.35-4.4$ & & ca. 55 & & Gasol et al. (1999) \\
\hline Freshwater pond & & nd & & & $6-24$ & Chrzanowski et al. (1984) \\
\hline Lake Windemere & Oligotrophic & nd & & & 7 & Porter et al. (1995) \\
\hline Church Beck & Polluted river & nd & & & 75 & Porter et al. (1995) \\
\hline Takayama River & Unpolluted & $0.28 \pm 0.08$ & $10 \pm 4$ & & $51 \pm 5$ & Yamaguchi \& Nasu (1997) \\
\hline Takiue River & Unpolluted & $0.86 \pm 0.14$ & $16 \pm 2$ & & $48 \pm 1$ & Yamaguchi \& Nasu (1997) \\
\hline Kuwazu River & Polluted & $4.9 \pm 0.74$ & $15 \pm 2$ & & $72 \pm 4$ & Yamaguchi \& Nasu (1997) \\
\hline Kitahashi River & Polluted & $5.7 \pm 0.65$ & $28 \pm 2$ & & $86 \pm 2$ & Yamaguchi \& Nasu (1997) \\
\hline Mediterranean & & $0.67-0.98$ & $3-8$ & & $7-12$ & Catala et al. (1999) \\
\hline 3 freshwater systems & Meso- to eutrophic & $4.4-10.9$ & $3-48$ & $42-70$ & $3-15$ & This study \\
\hline 5 estuarine locations & Eutrophic & $8.7-24.1$ & $1-21$ & $52-76$ & $2-24$ & This study \\
\hline 4 Baltic coast sites & Mesotrophic & $1.2-2.8$ & $3-23$ & $22-81$ & $3-11$ & This study \\
\hline
\end{tabular}

tigations on substrate uptake and FISH (e.g. Lee et al. 1999) represents another methodological strategy to relate activity and taxonomy.

Another experiment of great ecological interest would be the combination of the autoradiographic study on substrate uptake with the fluorescent labelling of hydrolytically active bacteria. That would eventually help to solve the questions about the fate of the enzymatically degraded particulate or, at least, polymeric organic matter to oligo- and monomeric compounds and the regulation of extracellular and periplasmatic enzyme activity, as they were addressed by Chróst (1990). To which extent can the degrading micro-organisms take the hydrolysis products up by themselves? Is the enzymatical hydrolysis a main source of readily available organic substrates? How can the supply of polymeric organic substrate induce the expression of extracellular and periplasmatic hydrolytic enzymes? The fluorescent labels for cellular hydrolytic enzymes will also provide a new tool to localise active cells in aggregates or on sediment particles where, besides the respiration of organic carbon, its hydrolysis is an important transformation process.

In aquatic microbial ecology, most hydrolytical enzyme activities are attributed to heterotrophic bacteria except for alkaline phosphatase (Chróst 1990). The application of substrates for cellular hydrolytical enzymes will also reveal the percentage contribution of other organisms to enzymatic hydrolysis. At least for cellular esterases, there are numerous results on yeasts or algae. The explanation of rather high percentages of enzyme activities in fractions that cannot pass through $3 \mu \mathrm{m}$ filters, being due solely to the high activity of attached bacteria (Hübener et al. 1996, Hoppe et al. 1998), is to be questioned.

Acknowledgements. We thank Astrid Hammer and Michael Kuhn for linguistic improvements.

\section{LITERATURE CITED}

Alexander E, Pham D, Steck TR (1999) The viablebutnonculturable condition is induced by copper in Agrobacterium tumefaciens and Rhizobium leguminosarum. Appl Environ Microbiol 65:3754-3756

Barcina I, Gonzales JM, Iriberri J, Egea L (1989) Effect of visible light on progressive dormancy of Escherichia coli cells during the survival process in natural fresh water. Appl Environ Microbiol 55:246-251

Bell PJL, Deere D, Shen J, Chapman B, Bissinger PH, Attfield PV, Veal DA (1998) A flow cytometric method for rapid selection of novel industrial yeast hybrids. Appl Environ Microbiol 64:1669-1672

Bernard L, Courties C, Duperray C, Schäfer H, Muyzer G, Lebaron P (2001) A new approach to determine the genetic diversity of viable and active bacteria in aquatic 
ecosystems. Cytometry 43:314-321

Boulos L, Prevost M, Barbeau B, Coallier J, Desjardins R (1999) LIVE/DEAD BacLight: application of a new rapid staining method for direct enumeration of viable and total bacteria in drinking water. J Microbiol Methods 37 : $77-86$

Breeuwer P, Drocourt JL, Rombouts FM, Abee T (1994) Energy-dependent, carrier-mediated extrusion of carboxyfluorescein from Saccharomyces cerevisiae allows rapid assessment of cell viability by flow cytometry. Appl Environ Microbiol 60:1467-1472

Breeuwer P, Drocourt JL, Bunschoten N, Zwietering MH, Rombouts FM, Abee T (1995) Characterization of uptake and hydrolysis of fluorescein diacetate and carboxyfluorescein diacetate by intracellular esterases in Saccharomyces cerevisiae, which result in accumulation of fluorescent product. Appl Environ Microbiol 61:1614-1619

Bunthof CJ, van den Braak S, Breeuwer P, Rombouts FM, Abee $\mathrm{T}$ (1999) Rapid fluorescence assessment of the viability of stressed Lactococcus lactis. Appl Environ Microbiol 65:3681-3689

Caro A, Got P, Baleux B (1999) Physiological changes of Salmonella typhimurium cells under osmotic and starvation conditions by image analysis. FEMS Microbiol Lett 179: 265-273

Catala P, Parthuisot N, Bernard L, Baudart J, Lemarchand K, Lebaron P (1999) Effectiveness of CSE to counterstain particles and dead bacterial cells with permeabilised membranes: application to viability assessment in waters. FEMS Microbiol Lett 178:219-226

Choi JW, Sherr EB, Sherr BF (1996) Relation between presence-absence of a visible nucleoid and metabolic activity in bacterioplankton cells. Limnol Oceanogr 41:1161-1168

Chróst RJ (1990) Microbial ectoenzymes in aquatic environments. In: Overbeck J, Chróst RJ (eds) Aquatic microbial ecology: biochemical and molecular approaches. Springer-Verlag, New York, p 47-78

Chrzanowski TH, Crotty RD, Hubbard JG, Welch RP (1984) Applicability of the fluorescein diacetate method of detecting active bacteria in freshwater. Microb Ecol 10: 179-185

Clarke RG, Pinder AC (1998) Improved detection of bacteria by flow cytometry using a combination of antibody and viability markers. J Appl Microbiol 84:577-584

del Giorgio PA, Scarborough G (1995) Increase in the proportion of metabolically active bacteria along gradients of enrichment in freshwater and marine plankton: implications for estimates of bacterial growth and production rates. J Plankton Res 14:1905-1924

del Giorgio PA, Gasol JM, Vaqué D, Mura P, Agustí S, Duarte CM (1996) Bacterioplankton community structure: protists control net production and the proportion of active bacteria in a coastal marine community. Limnol Oceanogr 41: 1169-1179

Deutsch M, Kaufman M, Shapiro H, Zurgil N (2000) Analysis of enzyme kinetics in individual living cells utilizing fluorescence intensity and polarization measurements. Cytometry 39:36-44

Diaper JP, Tither K, Edwards C (1992) Rapid assessment of bacterial viability by flow cytometry. Appl Environ Microbiol 38:268-272

Dive C, Cox H, Watson JV, Workman P (1988) Polar fluorescein derivatives as improved substrate probes for flow cytoenzymological assay of cellular esterases. Mol Cell Probes 2:131-145

Dorsey J, Yentsch CM, Mayo S, McKenna C (1989) Rapid analytical technique for the assessment of cell metabolic activity in marine microalgae. Cytometry 10:622-628

Dufour P, Colon M (1992) The tetrazolium reduction method for assessing the viability of individual bacterial cells in aquatic environments: improvements, performance and applications. Hydrobiologia 232:211-218

Ferguson RL, Buckley EN, Palumbo, AV (1984) Response of marine bacterioplankton to differential filtration and confinement. Appl Environ Microbiol 47:49-55

Fiksdal L, Tryland I (1999) Effect of u.v. light irradiation, starvation and heat on Escherichia coli $\beta$-D-galactosidase activity and other potential viability parameters. J Appl Microbiol 87:62-71

Gasol JM, Zweifel UL, Peters F, Fuhrman JA, Hagström ^̊ (1999) Significance of size and nucleic acid content heterogeneity as measured by flow cytometry in natural planktonic bacteria. Appl Environ Microbiol 65:4475-4483

Glöckner FO, Fuchs BM, Amann R (1999) Bacterioplankton compositions of lakes and oceans: a first comparison based on fluorescence in situ hybridization. Appl Environ Microbiol 65:3721-3726

Gocke K, Rheinheimer G (1991) Influence of eutrophication on bacteria in two fjords of the western Baltic. Int Rev Gesamten Hydrobiol 76:371-385

Hagström Å, Larsson U, Hörstedt P, Normark S (1979) Frequency of dividing cells, a new approach to the determination of bacterial growth rates in aquatic environments. Appl Environ Microbiol 37:805-812

Haugland RP (2001) Handbook of fluorescent probes and research chemicals. Web Edition. http://www.probes.com

Heissenberger A, Leppard GG, Herndl GJ (1996) Relationship between the intracellular integrity and the morphology of the capsular envelope in attached and free-living marine bacteria. Appl Environ Microbiol 62:4521-4528

Hoppe HG, Giesenhagen HC Gocke, K (1998) Changing patterns of bacterial substrate decomposition in a eutrophication gradient. Aquat Microb Ecol 15:1-13

Hübener T, Klinkenberg G, Börner R (1996) Enzymatische Aktivität des Bakterio- und Phytoplanktons der Warnow in den Jahren 1992-1993. Vom Wasser 87:409-416 (with English Abstract)

Jackson PR, Pappas MG, Hansen BD (1985) Fluorogenic substrate detection of viable intracellular and extracellular pathogenic protozoa. Science 227:435-438

Jepras RI, Carter J, Pearson SC, Paul FE, Wilkinson MJ (1995) Development of a robust flow cytometric assay for determining numbers of viable bacteria. Appl Environ Microbiol 61:2696-2701

Jepras RI, Paul FE, Pearson SC, Wilkinson MJ (1997) Rapid assessment of antibiotic effects on Escherichia coli by bis(1,3-dibutylbarbituric acid) trimethine oxonol and flow cytometry. Antimicrob Agents Chemother 41:2001-2005

Jochem FJ (1999) Dark survival strategies in marine phytoplankton assessed by cytometric measurement of metabolic activity with fluorescein diacetate. Mar Biol 135: 721-728

Karner M, Fuhrman JA (1997) Determination of active marine bacterioplankton: a comparison of universal 16S rRNA probes, autoradiography, and nucleiod staining. Appl Environ Microbiol 63:1208-1213

Kell DB, Kaprelyants AS, Weichart DH, Harwood CR, Barer MR (1998) Viability and activity in readily culturable bacteria: a review and discussion of the practical issues. Antonie Leeuwenhoek 73:169-187

King LK, Parker BC (1988) A simple, rapid method for enumerating total viable and methabolically active bacteria in groundwater. Appl Environ Microbiol 54:1630-1631

Klinkenberg G, Schumann R (1995) Abundance changes of 
autotrophic and heterotrophic picoplankton in the Zingster Strom, a shallow, tideless estuary south of the DarssZingst Peninsula (southern Baltic Sea). Arch Hydrobiol 134:359-377

Kogure K, Simidu U, Taga N (1979) A tentative direct microscopic method for counting living marine bacteria. Can J Microbiol 25:415-420

Lebaron P, Catala P, Parthuisot N (1998a) Effectiveness of SYTOX Green stain for bacterial viability assessment. Appl Environ Microbiol 64:2697-2700

Lebaron P, Parthuisot N, Catala P (1998b) Comparison of blue nucleic acid dyes for flow cytometric enumeration of bacteria in aquatic systems. Appl Environ Microbiol 64: 1725-1730

Lee N, Nielsen PH, Andreasen KH, Juretschko S, Nielsen JL, Schleifer KH, Wagner M (1999) Combination of fluorescent in situ hybridization and microautoradiography-a new tool for structure-function analyses in microbial ecology. Appl Environ Microbiol 65:1289-1297

Li A, Stoecker DK, Coats DW, Adam EJ (1996) Ingestion of fluorescently labeled and phycoerythrin-containing prey by mixotrophic dinoflagellates. Aquat Microb Ecol 10: 139-147

López-Amorós R, Comas J, Vives-Rego J (1995) Flow cytometric assessment of Escherichia coli and Salmonella typhimurium starvation-survival in seawater using rhodamine 123, propidium iodide, and oxonol. Appl Environ Microbiol 61:2521-2526

Lovejoy C, Legendre L, Klein B, Tremblay JÉ, Ingram RG, Therriault JC (1996) Bacterial activity during early winter mixing (Gulf of St. Lawrence, Canada). Aquat Microb Ecol 10:1-13

Meyer Reil LA (1978) Autoradiography and epifluorescence microscopy combined for the determination of number and spectrum of actively metabolizing bacteria in natural waters. Appl Environ Microbiol 36:506-512

Miskin I, Rhodes G, Lawlor K, Saunders JR, Pickup RW (1998) Bacteria in post-glacial freshwater sediments. Microbiology 144:2427-2439

Mortimer FC, Mason DJ, Gant VA (2000) Flow cytometric monitoring of antibiotic-induced injury in Escherichia coli using cell-impermeant fluorescent probes. Antimicrob Agents Chemother 44:676-681

Murphy AM, Cowles TJ (1997) Effects of darkness on multiexcitation in vivo fluorescence and survival in a marine diatom. Limnol Oceanogr 42:1444-1453

Novo DJ, Perlmutter NG, Hunt RH, Shapiro HM (2000) Multiparameter flow cytometric analysis of antibiotic effects on membrane potential, membrane permeability, and bacterial counts of Staphylococcus aureus and Micrococcus luteus. Antimicrob Agents Chemother 44:827-834

Porter KG, Feig YS (1980) The use of DAPI for counting and identifying aquatic microflora. Limnol Oceanogr 25: 943-948

Porter J, Diaper J, Edwards C, Pickup R (1995) Direct measurements of natural planktonic bacterial community viability by flow cytometry. Appl Environ Microbiol 61: 2783-2786

Posch T, Pernthaler J, Alfreider A, Psenner R (1997) Cellspecific respiratory activity of aquatic bacteria studied with the tetrazolium reduction method, cyto-clear slides, and image analysis. Appl Environ Microbiol 63:867-873

Rodriguez GG, Phipps D, Ishiguro K, Ridgway HF (1992) Use of a fluorescent redox probe for direct visualization of

Editorial responsibility: James Hollibaugh, Athens, Georgia, USA actively respiring bacteria. Appl Environ Microbiol 58: 1801-1808

Roth BL, Poot M, Yue ST, Millard PJ (1997) Bacterial viability and antibiotic susceptibility testing with SYTOX Green nucleic acid stain. Appl Environ Microbiol 63:2421-2431

Saxena G, Lysek G (1993) Observation of nematophagous fungi in natural soils by fluorescence microscopy and their correlation with isolation. Mycol Res 97:1005-1011

Schading RL, Carruthers RI, Mullin-Schading BA (1995) Rapid determination of conidial viability for entomopathogenic hyphomycetes using fluorescence microscopy techniques. Biocontrol Sci Technol 5:201-208

Schumann R, Rieling T, Görs S, Hammer A, Selig U, Schiewer U (2003) Viability of bacteria from different aquatic habitats. I. Environmental conditions and productivity. Aquat Microb Ecol 32:121-135

Sherr BF, Sherr EB, McDaniel J (1992) Effect of protistan grazing on the frequency of dividing cells in bacterioplankton assemblages. Appl Environ Microbiol 58: 2381-2385

Sherr BF, del Giorgio P, Sherr EB (1999a) Estimating abundance and single-cell characteristics of respiring bacteria via the redox dye CTC. Aquat Microb Ecol 18:117-131

Sherr EB, Sherr BF, Sigmon CT (1999b) Activity of marine bacteria under incubated and in situ conditions. Aquat Microb Ecol 20:213-223

Sommaruga R, Conde D (1997) Seasonal variability of metabolically active bacterioplankton in the euphotic zone of a hypertrophic lake. Aquat Microb Ecol 13:241-248

Suzuki MT, Sherr EB, Sherr BF (1993) DAPI direct counting underestimates bacterial abundances and average cell size compared to AO direct counting. Limnol Oceanogr 38:1566-1570

Veal DA, Deere D, Ferrari B, Piper J, Attfield PV (2000) Fluorescence staining and flow cytometry for monitoring microbial cells. J Immunol Methods 243:191-210

Virta M, Lineri S, Kankaanpää P, Karp M, Peltonen K, Nuutila J, Lilius EM (1998) Determination of complementmediated killing of bacteria by viability staining and bioluminescence. Appl Environ Microbiol 64:515-519

Weichart D, McDougald D, Jacobs D, Kjelleberg S (1997) In situ analysis of nucleic acids in cold-induced nonculturable Vibrio vulnificus. Appl Environ Microbiol 63: $2754-2758$

Williams S, Verity PG, Beatty T (1995) A new staining technique for dual identification of plankton and detritus in seawater. J Plankton Res 17 2037-2047

Williams SC, Hong Y, Danavall DCA, Howard-Jones MH, Gibson D, Frischer ME, Verity PG (1998) Distinguishing between living and nonliving bacteria: evaluation of the vital stain propidium iodide and its combined use with molecular probes in aquatic samples. J Microbiol Methods 32:225-236

Yamaguchi N, Nasu M (1997) Flow cytometric analysis of bacterial respiratory and enzymatic activity in the natural aquatic environment. J Appl Microbiol 83:43-52

Yokoyama H, Danjo T, Ogawa K, Wakabayashi H (1997) A vital staining technique with fluorescein diacetate (FDA) and propidium iodide (PI) for the determination of viability of myxosporean and actinosporean spores. J Fish Dis 20:281-286

Zweifel UL, Hagström s (1995) Total counts of marine bacteria include a large fraction of non- nucleoid-containing bacteria (ghosts). Appl Environ Microbiol 61:2180-2185

Submitted: March 22, 2002; Accepted: February 5, 2003

Proofs received from author(s): May 26, 2003 